\title{
LEACHING CHARACTERISTICS AND MINERALOGICAL CONTROL OF CHROMIUM IN ELECTRIC-ARC-FURNACE STAINLESS-STEEL SLAG
}

\author{
LUŽENJE IN MINERALOŠKA KONTROLA KROMA V ŽLINDRI \\ NERJAVNEGA JEKLA IZ ELEKTROOBLOČNE PEČI
}

\author{
Ya-Jun Wang ${ }^{1,2}$, Ya-Nan Zeng ${ }^{*}$, Jun-Guo Li ${ }^{1{ }^{*}}$, Zhi-Yuan Gao ${ }^{3}$ \\ ${ }^{1}$ School of Metallurgy and Energy, North China University of Science and Technology, 063009 Tangshan, P. R. China \\ ${ }^{2}$ School of Materials and Metallurgy, Northeastern University, 110819 Shenyang, P. R. China \\ ${ }^{3}$ Tangshan Research Academy of Environmental Planning, 063000, Tangshan, P. R. China
}

Prejem rokopisa - received: 2020-08-10; sprejem za objavo - accepted for publication: 2020-10-26

This study focuses on evaluating the leachability of chromium in Electric-Arc-Furnace stainless-steel slag (EAFS) from the perspective of mineralogical control. Mineral-phase identification results showed that EAFS mainly comprised merwinite, magnetite, dicalcium silicate, calcium aluminosilicate, eskolaite, spinel, and perovskite. The chromium in the EAFS was mainly present in the $\mathrm{Mg}-\mathrm{Cr}$ spinel, $\mathrm{Fe}-\mathrm{Cr}$ alloy, or distributed in the form of oxide in the matrix phase, merwinite. When undergoing leaching, the leachate of the EAFS was alkaline and reducing, and a portion of the chromium in the slag was released into the leachate and existed mainly in a trivalent state. In the early stage of leaching, the rapid dissolution of chromium-bearing silicate minerals led to a rapid increase in the concentration of trivalent chromium. However, in the middle and late stages ( $>15$ days) of leaching, the chromium concentration reached stable values. The geochemical model of chromium leaching from the EAFS demonstrated that the simulated values of the chromium concentration were consistent with the batch-leaching test values. The primary phase $\mathrm{Cr}_{2} \mathrm{O}_{3}$ in the EAFS controlled the chromium concentration in the leachate. After entering the leachate, trivalent chromium could be presented as $\mathrm{Cr}(\mathrm{OH})_{4}^{-}$because $\mathrm{Cr}(\mathrm{III})$-hydroxide was unstable in the alkaline leachate.

Keywords: EAF slag, chromium, mineral phase, geochemical model, leaching, PHREEQC

V študiji so se avtorji osredotočili na ovrednotenje izluženja kroma iz žlindre nerjavnega jekla v elektro obločni peči (EAFS; angl.: electric arc furnace slag) s stališča mineraloške kontrole. Rezultati identifikacije mineralne faze so pokazali, da EAFS vsebuje v glavnem mervinite, magnetit, dikalcijev silikat, kalcijev alumosilikat, eskolait, špinel in perovskit. Krom je v EAFS prisoten predvsem v Mg-Cr špinelu, zlitini Fe-Cr ali pa je porazdeljen v obliki oksida v matrici mervinitne faze. Med luženjem je nastali izlužek EAFS bazičen (alkalen) in reduciran. Sproščeni delež kroma iz žlindre je v glavnem v trivalentnem stanju. V začetni fazi luženja pride do hitrega raztapljanja mineralov v katerih se nahaja krom, kar vodi do močnega povečanja koncentracije trivalentnega kroma. Vendar pa v srednji in zadnji fazi luženja (več kot 15 dni) vsebnost kroma doseže stabilno vrednost. Geokemijski model izluženja kroma iz EAFS je pokazal, da se simulirane vrednosti vsebnosti kroma ujemajo s praktičnimi vrednostmi v šarži. Primarna $\mathrm{Cr}_{2} \mathrm{O}_{3}$ faza v EAFS kontrolira vsebnost kroma v izluženem. Tri valentni krom je v izluženem lahko prisoten kot $\mathrm{Cr}(\mathrm{OH})_{4}^{-}$, ker je bil Cr(III)-hidroksid nestabilen v alkalnem izlužku.

Ključne besede: elektroobločna peč, žlindra nerjavnega jekla, krom, mineralna faza, geokemijski model, luženje, programsko orodje PHREEQC

\section{INTRODUCTION}

EAFS is a by-product generated during the preliminary smelting of stainless steel using an electric arc furnace, and its chromium content is typically higher than in ordinary steel slag. ${ }^{1}$ Over time, rainwater can leach chromium, in the form of trivalent chromium $(\mathrm{Cr}(\mathrm{III}))$ or hexavalent chromium $(\mathrm{Cr}(\mathrm{VI}))$, from the slag present in landfills. ${ }^{2}$ The ease of leaching and the toxicity of the $\mathrm{Cr}(\mathrm{VI})$ from EAFS has led to extensive ecosystem deterioration after contaminating water and soil..$^{3-5} \mathrm{Cr}$ (III) is generally harmless to the environment because of its lower mobility and toxicity. ${ }^{6}$ However, long-term exposure of $\mathrm{Cr}$ (III) to humans can lead to allergic skin reactions and even cancer. ${ }^{7}$

*Corresponding author's e-mail:

zengyanann@126.com (Ya-Nan Zeng)
During the stacking and recycling of EAFS, concerns about the leaching of chromium mainly focused on the leaching toxicity and the mineralogical control of chromium. Extensive research has been performed on EAFS to study chromium leaching behavior, aiming at assessing its toxicity. ${ }^{8-10}$ R.Wang et al. ${ }^{11}$ tested chromium leachability when EAFS was used as the cement admixture and stated that the ecological risk of chromium released from EAFS is minimal because chromium in the leachates is mainly present as $\mathrm{Cr}$ (III) at a concentration of $0.01 \mathrm{mg} / \mathrm{L}$ to $0.05 \mathrm{mg} / \mathrm{L}$. However, because $\mathrm{Cr}(\mathrm{VI})$ has strong carcinogenic properties, ${ }^{12}$ if $\mathrm{Cr}(\mathrm{VI})$ is observed in the leachate of EAFS, the risk of leaching cannot be ignored.

Since the smelting stage of an electric arc furnace is a reducing environment, the low oxygen potential controls the oxidation of metals and metalloids, and chromium in EAFS mainly exists in the metallic state and as $\mathrm{Cr}(\mathrm{III})$. 
Table 1: Chemical composition of the EAFS

\begin{tabular}{|c|c|c|c|c|c|c|c|c|c|c|}
\hline Oxides & $\mathrm{CaO}$ & $\mathrm{SiO}_{2}$ & $\mathrm{MgO}$ & $\mathrm{Al}_{2} \mathrm{O}_{3}$ & $\mathrm{Fe}_{2} \mathrm{O}_{3}$ & $\mathrm{FeO}$ & $\mathrm{TiO}_{2}$ & $\mathrm{MnO}_{2}$ & $\mathrm{Cr}$ & others \\
\hline Contents (w/\%) & 38.64 & 24.01 & 12.63 & 9.55 & 2.50 & 1.82 & 1.61 & 0.88 & 4.21 & 4.15 \\
\hline
\end{tabular}

Metallic chromium can be separated and recovered through crushing, fine grinding, and magnetic separation. The remaining $\mathrm{Cr}(\mathrm{III})$ is mainly present in $\mathrm{Ca}-\mathrm{Mg}-\mathrm{Al}$ silicates and spinel minerals. $\mathrm{Ca}-\mathrm{Mg}-\mathrm{Al}$ silicates can be hydrolyzed to release chromium, while spinel minerals are insoluble. ${ }^{13}$ Researchers considered enriching chromium to insoluble spinel through the hot-slag-modification method. According to the leaching index Factor $\mathrm{sp}$ (Factor $\mathrm{sp}=0.2 \mathrm{MgO}+1.0 \mathrm{Al}_{2} \mathrm{O}_{3}+$ $\mathrm{nFeOx}-0.5 \mathrm{Cr}_{2} \mathrm{O}_{3}$ ) constructed by M. Kuhn ${ }^{14}$ when Factor sp is higher than $5 \%$, the chromium leaching ratio decreases. By melting at high temperatures, adding $\mathrm{MgO}, \mathrm{Al}_{2} \mathrm{O}_{3}, \mathrm{FeO}_{\mathrm{x}}$, etc. to the slag can reduce the leaching rate of chromium in the stainless-steel slag. PChaurand et al. ${ }^{4}$ stated that the leachability of chromium is controlled by the formation of spinel phases similar to chromite. Moreover, W. J. Deutsch ${ }^{15}$ indicated that such secondary phases as $\mathrm{Cr}$ (III)-hydroxide may determine the release of chromium from the solid phases into a liquid phase.

To explore the leaching characteristics of solid wastes, researchers have established some geochemical models based on detailed mineralogical analyses in conjunction with leaching tests. V. Ettler et al. ${ }^{16}$ applied PHREEQC to analyze $\mathrm{Pb}$ leaching from the secondary $\mathrm{Pb}$ smelter air-pollution-control residues and concluded that anglesite was the main solubility-controlling phase for $\mathrm{Pb}$ leaching. A. M. Fällman ${ }^{17}$ found that the dissolution of a $\mathrm{BaSO}_{4}$ and $\mathrm{Ba}(\mathrm{S}, \mathrm{Cr}) \mathrm{O}_{4}$ solid solution controlled the barium and chromium concentrations in the leachates according to the results of the PHREEQC simulation. These studies provided an effective means to establish a leaching model of chromium from EAFS.

This work was aimed at assessing the leachability of chromium in EAFS and exploring its leaching mechanism. X-ray diffraction (XRD) was used to determine the mineralogical composition of EAFS. Scanning electron microscopy with energy-dispersive spectroscopy (SEM/EDS) microscope system was used to observe the occurrence state of chromium in EAFS. Sequential leaching tests under three liquid-to-solid ratios were performed to obtain the experimental data. A thermodynamic model was established using PHREEQC software to predict the leaching concentration of chromium in the leachate and to determine the mineralogical phase that controls the release of chromium in EAFS.

\section{EXPERIMENTAL PART}

\subsection{Materials}

The EAFS used for this work was collected from a Chinese stainless-steel plant. The obtained EAFS was first crushed by a crusher, and the Fe-Cr alloy metal drop was extracted by a magnet. Then it was sieved using a 200-mesh sieve. After being dried for $6 \mathrm{~h}$ at $105^{\circ} \mathrm{C}$ to remove the free moisture, the EAFS's chemical composition was analyzed by X-ray fluorescence (XRF, DE 2000) and then quantified with the appropriate software and exported as oxide form. The results are shown in Table 1.

As shown in Table 1, the main chemical components of EAFS were $\mathrm{CaO}, \mathrm{SiO}_{2}, \mathrm{MgO}$, and $\mathrm{Al}_{2} \mathrm{O}_{3}$, with $\mathrm{CaO}$ and $\mathrm{SiO}_{2}$ (38.64\% and $24.01 \%$, respectively) being significantly higher than the other components. The triple alkalinity of EAFS calculated by Equation (1) was 2.14, which indicated that the EAFS should be classified as alkaline steel slag. In addition, EAFS contained a certain amount of $\mathrm{Fe}_{2} \mathrm{O}_{3}, \mathrm{FeO}, \mathrm{TiO}_{2}$, and $\mathrm{MnO}_{2}$. The chromium content of EAFS was $4.21 \%$, which was higher than other common types of steel slag.

$$
R=\frac{(\mathrm{CaO} \%+\mathrm{MgO} \%)}{\mathrm{SiO}_{2} \%} \times 100 \%
$$

\subsection{Characterization methods}

The mineral phase compositions of the EAFS were analyzed by X-ray diffraction (XRD) using an X-ray diffractometer (D/Max-RB, Rigaku) with $\mathrm{Cu}-K_{\alpha}$ radiation at $40 \mathrm{kV}$ and $100 \mathrm{~mA}$, a scanning rate of $0.03^{\circ}(2 \theta)$ every 6 seconds, and diffraction angles that ranged from $10^{\circ}$ to $90^{\circ}$. MDI Jade 9 software coupled with the ICDD PDF 2009 database was utilized for qualitative and quantitative analyses of the mineral phases in the EAFS.

The microstructure of the EAFS was examined using SEM (Hitachi S-4800) on an instrument equipped with energy-dispersive spectrometry (EDS, Bruker). The EAFS powder was inlaid on the bottom surface of a $(1 \times 1) \mathrm{cm}$ phenolic resin cube to prepare the SEM/EDS sample. After the sample was completely solidified, the side inlaid with EAFS was polished and sprayed with a gold film to give it conductivity. The electron beam operating voltage of the SEM was $20 \mathrm{kV}$, and the count rate of the EDS was 4000-5000 counts/s.

\subsection{Sequential leaching}

The sequential leaching test used in this research was designed according to the EN12457-2, which was recommended by the European Committee for Standardization as the preferred choice to conduct the compliance test for the leaching of granular waste materials and sludges because of its simplicity, reproducibility, and reliability.

Three liquid-solid $(L / S)$ ratio leaching systems were prepared by adding $10 \mathrm{~g}, 50 \mathrm{~g}$, and $100 \mathrm{~g}$, respectively, of EAFS into $1 \mathrm{~L}$ of deionized water in an Erlenmeyer 
flask. The flasks were then tightly stoppered to prevent air from entering during the leaching process. The Erlenmeyer flasks were fixed in a horizontal shaker and subjected to continuous shaking at a rate of $20 \mathrm{~min}^{-1}$ for 20 days. During the sequential leaching process, $80 \mathrm{~mL}$ of the leachate supernatant was sampled every $24 \mathrm{~h}$, and the same volume of deionized water was supplemented to maintain the $L / S$ ratio. The sampled leachates were filtered through $0.22-\mu \mathrm{m}$ membrane filters. The $\mathrm{pH}$ and redox potential (Eh) of the sampled leachate was measured immediately. After filtering through a $0.22-\mu \mathrm{m}$ membrane filter, chromium-ion concentration detection was performed on the sampled leachate. Hexavalent chromium and total chromium concentration in the leachate were analyzed using UV-visible spectrophotometry by the diphenylcarbazide method (GB/T 15555.4-1995) in conjunction with the oxidation of ammonium peroxydisulfate. ${ }^{18}$ The trivalent chromium concentration was calculated by the subtraction method.

\subsection{Geochemical modeling}

To explore the leaching characteristics and identify the controlling phases of chromium in the EAFS, a geochemical model was established using PHREEQC software based on the dissolution of the primary phases and the precipitation of secondary phases. The supplementary thermodynamic data used in this model were derived from the MINTEQ database and extended with minor modifications as described by J. W. Ball et al. ${ }^{19}$ To establish the model, an input file that specified the structure of the modeling problem, the input data, and the required computed results were set up and used in the PHREEQC software.

To simulate the chromium concentration in the leachates, data about the element content and mineralogical composition in the EAFS should be proposed. According to the $\mathrm{XRD}$ results, the primary phases were merwinite $\left(\mathrm{Ca}_{3} \mathrm{Mg}\left(\mathrm{SiO}_{4}\right)_{2}\right)$, dicalcium silicate $\left(\mathrm{Ca}_{2} \mathrm{SiO}_{4}\right)$, magnetite $\left(\mathrm{Fe}_{3} \mathrm{O}_{4}\right)$, gehlenite $\left(\mathrm{Ca}_{2} \mathrm{Al}_{2} \mathrm{SiO}_{7}\right)$, eskolaite $\left(\mathrm{Cr}_{2} \mathrm{O}_{3}\right)$, magnesium chromate $\left(\mathrm{MgCr}_{2} \mathrm{O}_{4}\right)$, and perov-

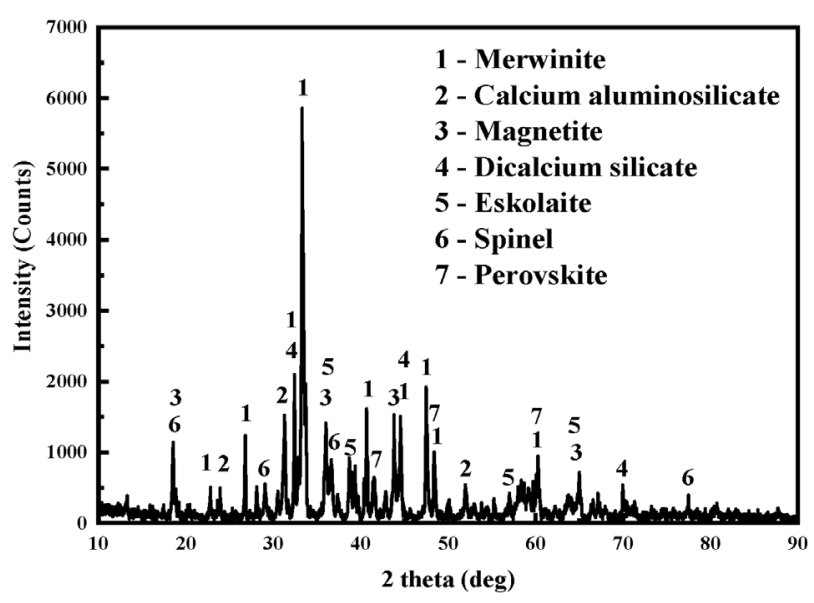

Figure 1: XRD pattern of the EAFS skite $\left(\mathrm{CaTiO}_{3}\right)$. During the leaching process, the primary phases undergo hydrolysis, dissolution, or precipitation to form amorphous or crystalline secondary phases. Accordingly, element concentrations in the leachates were governed by the dissolution/precipitation equilibrium of the primary and secondary phases in the aqueous solution. Generally, the saturation index (SI) is a parameter calculated by PHREEQC based on mass balance to determine the dissolution or precipitation of a mineral phase. SI is defined as $\log (\mathrm{Q} / \mathrm{K})$, where $\mathrm{Q}$ is the activity product, and $\mathrm{K}$ is the thermodynamic constant for a given dissolution reaction. ${ }^{20}$ The saturation index is a useful quantity to determine whether the water is saturated, undersaturated, or supersaturated for the given mineral. A positive SI (supersaturated state) indicates that the given mineral may be precipitated as a secondary phase. A negative SI (undersaturated state) indicates that the given mineral is not stable in the leachate and may dissolve. Minerals with $-1.5<\mathrm{SI}<1.5$ were considered to be the potential solubility-controlling minerals..$^{21,22}$ In this way, the mineral phases controlling the chromium concentration in leachate could be determined.

\section{RESULTS AND DISCUSSION}

\subsection{Mineralogical composition}

Figure 1 presents the XRD pattern of the EAFS. The EAFS mainly consisted of merwinite $\left(\mathrm{Ca}_{3} \mathrm{Mg}(\mathrm{SiO} 4)_{2}\right)$, magnetite $\left(\mathrm{Fe}_{3} \mathrm{O}_{4}\right)$, dicalcium silicate $\left(\mathrm{Ca}_{2} \mathrm{SiO}_{4}\right)$, calcium aluminosilicate $\left(\mathrm{Ca}_{2} \mathrm{Al}_{2} \mathrm{Si}_{2} \mathrm{O}_{8}\right)$, eskolaite $\left(\mathrm{Cr}_{2} \mathrm{O}_{3}\right)$, spinel $\left(\mathrm{Mg}(\mathrm{Cr}, \mathrm{Al})_{2} \mathrm{O}_{4}\right)$, and perovskite $\left(\mathrm{CaTiO}_{3}\right)$. This mineralogical characterization is similar to the results reported by other researchers. ${ }^{23,24}$

\subsection{Micromorphology}

Table 2: Element compositions of representative microdomains in the EAFS $(a / \%)$

\begin{tabular}{|c|c|c|c|c|c|c|c|c|}
\hline $\begin{array}{c}\text { Micro- } \\
\text { domain }\end{array}$ & $\mathrm{Ca}$ & $\mathrm{Si}$ & $\mathrm{Mg}$ & $\mathrm{Al}$ & $\mathrm{O}$ & $\mathrm{Cr}$ & $\mathrm{Fe}$ & $\mathrm{Ti}$ \\
\hline 1 & 21.86 & 10.31 & 6.04 & 0.25 & 61.54 & - & - & - \\
\hline 2 & 56.98 & 11.21 & 0.28 & - & 30.15 & 1.10 & 0.29 & - \\
\hline 3 & - & 12.99 & - & - & - & 45.78 & 34.18 & - \\
\hline 4 & 20.69 & 13.47 & 7.33 & 1.56 & 47.21 & 4.94 & 3.59 & 1.21 \\
\hline 5 & 21.39 & 10.64 & 6.94 & & 45.84 & - & - & - \\
\hline 6 & 33.46 & 15.49 & 2.28 & 3.71 & 44.15 & - & 0.29 & 0.62 \\
\hline 7 & - & - & 42.87 & 10.32 & 41.30 & 5.51 & - & - \\
\hline 8 & 27.26 & 13.84 & 7.65 & 0.63 & 50.14 & - & - & 0.48 \\
\hline 9 & - & - & - & - & - & 5.31 & 94.69 & - \\
\hline
\end{tabular}

Figure 2 depicts the micromorphology of the EAFS. It can be observed from Figure 2 that the cross-section of the EAFS particles mainly existed in an irregular plate form. Areas with different color contrast were observed at the slag particle interface, indicating that the chemical composition of these areas was different. Elemental compositions of representative points were tested using 


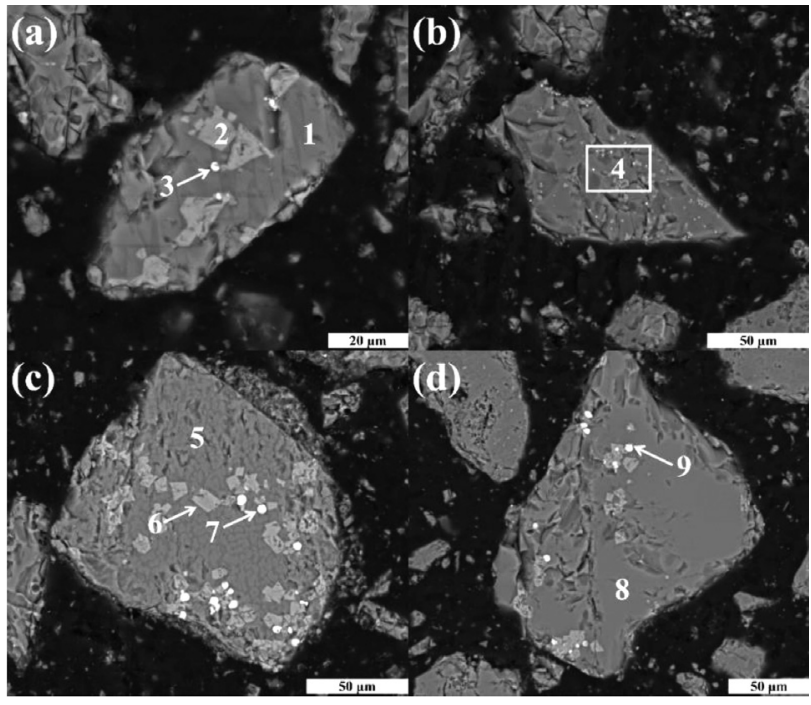

Figure 2: Microscopic morphology of the EAFSo

EDS detection based on color contrast, and the results are listed in Table 2.

The $\mathrm{Ca}-\mathrm{Mg}$ silicate phases were the matrix mineral phases of EAFS (Microdomains 1, 4, 5, and 8), and other

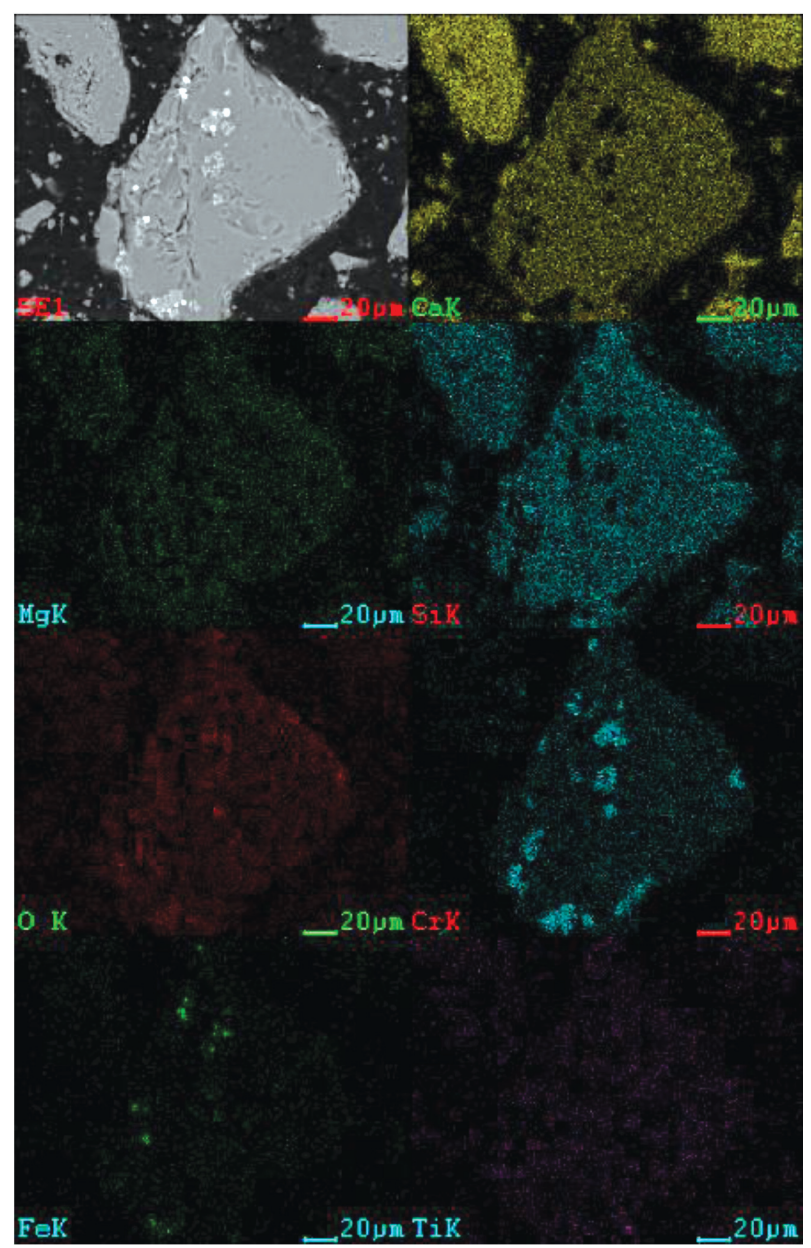

Figure 3: Elemental distribution of $\mathrm{Ca}, \mathrm{Mg}, \mathrm{Si}, \mathrm{O}, \mathrm{Cr}, \mathrm{Fe}, \mathrm{Ti}$ in the EAFS powder phases were encapsulated in it. Dicalcium silicate existed as a minor mineral phase in the merwinite matrix, and there were some trace mineral phases dissolved in it, such as eskolaite, spinel, or Fe-Cr alloy (Microdomains 2 and 6). Moreover, there were some miniscule dot-shaped occurrences of Fe-Cr alloy (Microdomains 3 and 9) and Cr-bearing spinel (Microdomain 7) unevenly distributed in the merwinite matrix.

Figure 3 shows the distribution of the main elements in a typical EAFS particle. From these images, calcium, magnesium, and silicon were evenly distributed throughout this slag particle. Chromium was mainly concentrated in certain areas, and the phases in these areas were mainly dicalcium silicate, $\mathrm{Fe}-\mathrm{Cr}$ alloy, and spinel.

\subsection{Characteristics of leachates}

The $\mathrm{pH}$ and redox potential (Eh) are two predominant parameters controlling the speciation and concentration of chromium in aqueous solution. Experimental measurements were performed to monitor the change in $\mathrm{pH}$ and Eh over time in the sequential leaching test, and the results are illustrated in Figure 4. On the first day of
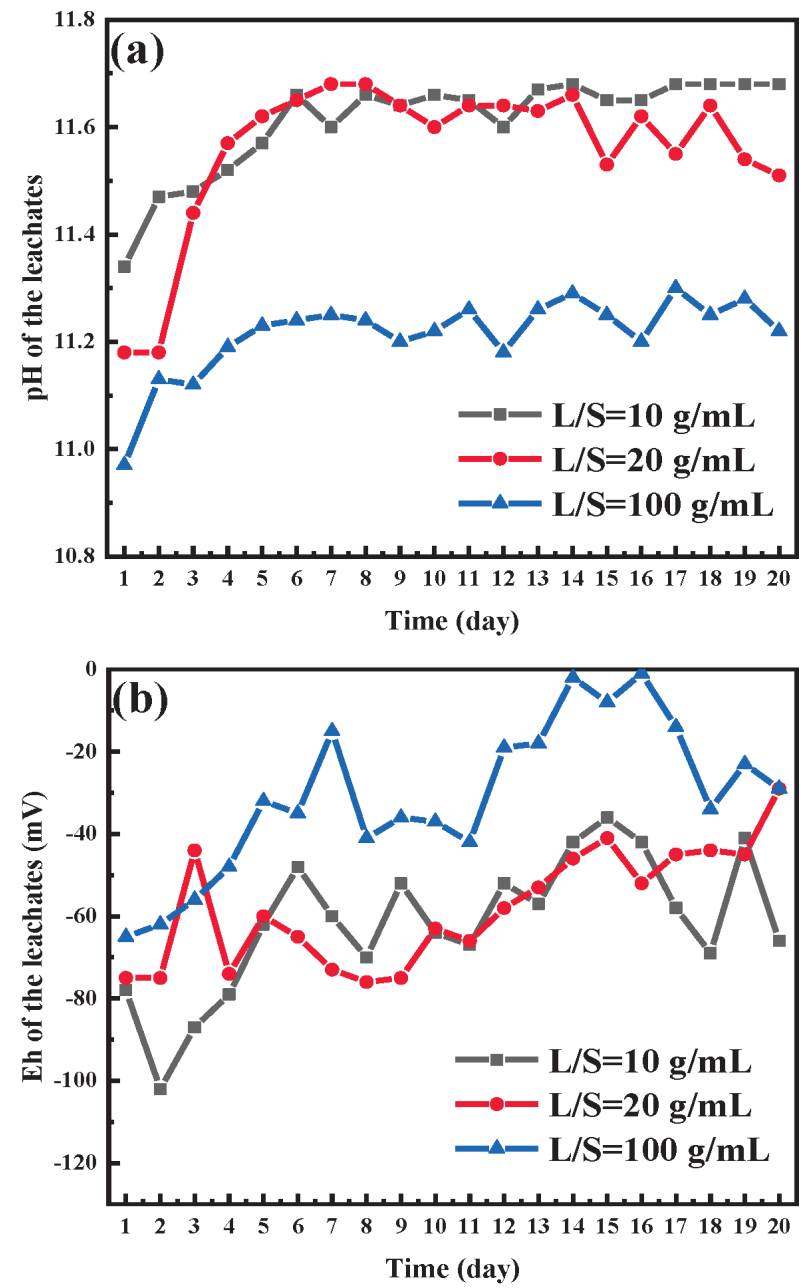

Figure 4: a) Evolution of $\mathrm{pH}$ and b) Eh of the leachates with different $L / S$ ratios 
leaching, the $\mathrm{pH}$ of the leachates rose sharply to above 11 (Figure 4a). This was mainly due to the dissolution of alkaline minerals, which resulted in the production of hydroxide ions. ${ }^{25}$ By day 6 , the $\mathrm{pH}$ value of the leachates reached equilibrium, and the equilibrium $\mathrm{pH}$ value decreased as the liquid-solid ratio increased. As the leaching time progressed, the soluble alkaline mineral phases in the EAFS reached their hydrolytic equilibrium states, and the hydroxide ion release rates reached their constant values. As the $L / S$ ratio increased, the dilution effect of more deionized water on the alkalinity was the main reason for the lower $\mathrm{pH}$ value of the larger $L / S$ ratio leaching system.

On the first day of leaching, the Eh decreased rapidly to a minimum value that was lower than $-60 \mathrm{mV}$ and then increased slightly thereafter (Figure 4b). During the entire leaching cycle, the leachates' Eh value change intervals were between $-30 \mathrm{mV}$ and $-76 \mathrm{mV}$, indicating a slight reducing property. During the leaching process, the Eh of the leachate was mainly controlled by the $\mathrm{Fe}^{2+} / \mathrm{Fe}^{3+}$ redox pair. ${ }^{25}$ Since EAFS was a Fe-bearing slag, the dissolution of $\mathrm{Fe}^{2+}$ ions caused the leachate to exhibit a certain degree of reduction. As the $L / S$ ratio increased, the Eh gradually increased from the dilution from deionized water reducing the concentration of $\mathrm{Fe}^{2+}$ ions in the leachate.

\subsection{Chromium leachability}

Leaching toxicity and ecological risk assessment rely on knowledge of the speciation of heavy metals and their concentrations in the leachates from the landfilled solid waste. In the sequential leaching test, the concentrations of trivalent and total chromium in the leachates were measured, and the results are illustrated in Figure 5. Concentrations of hexavalent chromium in the leachates ranged from 0 to $5.2 \times 10^{-3} \mathrm{mg} / \mathrm{L}$, while concentrations of trivalent chromium in the leachates ranged from $1.7 \times 10^{-2}$ to $8.4 \times 10^{-2} \mathrm{mg} / \mathrm{L}$. It can be concluded that due to the high alkalinity and reduction properties of the leachate,

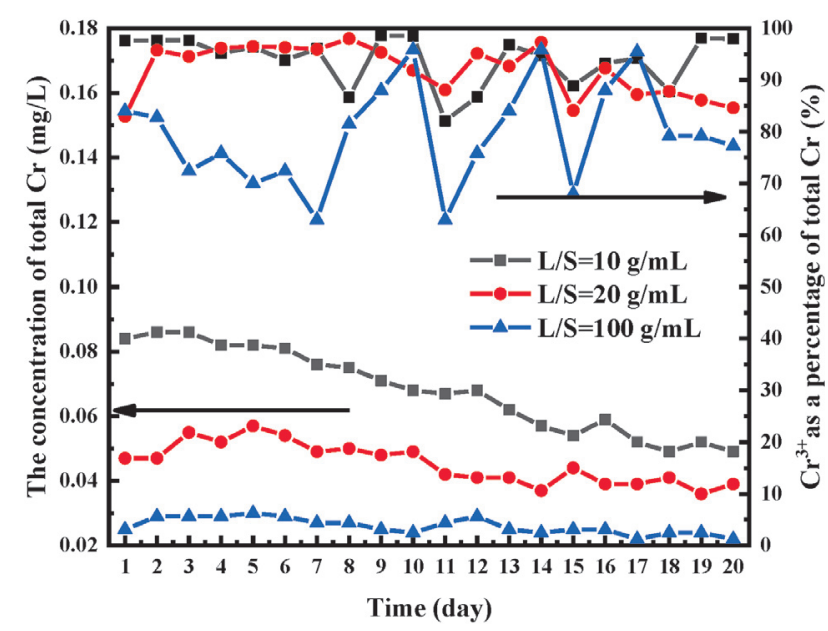

Figure 5: Chromium concentration in the leachate chromium in the leachate was mainly present in the trivalent form. The experiments performed by Chaurand et al. ${ }^{26}$ showed that chromium was trivalent in steel slag, and its speciation changed very little during water leaching and natural aging.

After leaching for one day, the concentrations of trivalent chromium in the leachates with $L / S$ ratios of $(0$, 20 , and 100$) \mathrm{g} / \mathrm{mL}$ were $8.2 \times 10^{-2} \mathrm{mg} / \mathrm{L}, 3.9 \times 10^{-2} \mathrm{mg} / \mathrm{L}$, and $2.1 \times 10^{-2} \mathrm{mg} / \mathrm{L}$, respectively. When the $L / S$ ratio was $10 \mathrm{~g} / \mathrm{mL}$, there was a tendency for the trivalent chromium concentration to decrease continuously over a period of 15 days and then stabilize at $5.2 \times 10^{-2} \mathrm{mg} / \mathrm{L}$. When the $L / S$ ratio was $20 \mathrm{~g} / \mathrm{mL}$, the trivalent chromium concentration increased slightly during the first five days and then declined for 15 days until stabilizing at $3.8 \times 10^{-2} \mathrm{mg} / \mathrm{L}$. When the $L / S$ ratio was $100 \mathrm{~g} / \mathrm{mL}$, the trivalent chromium concentration remained steady at $2.4 \times 10^{-2} \mathrm{mg} / \mathrm{L}$ throughout the leaching cycle.

The evolution of trivalent chromium under different $L / S$ ratios was different. The trivalent chromium in the leachates originated from the chromium-bearing minerals. As analyzed previously, chromium in EAFS was mainly dispersed in silicates, spinel-type phases, and $\mathrm{Fe}-\mathrm{Cr}$ alloy. Spinel-type phases were insoluble both in neutral and alkaline solutions, ${ }^{14}$ whereas the $\mathrm{Cr}_{2} \mathrm{O}_{3}$ dissolved in the $\mathrm{Ca}-\mathrm{Mg}$-silicates, known as pseudo-binary phases, were freely soluble both in neutral and alkaline solutions. ${ }^{27}$ The rapid dissolution of these pseudo-binary phases led to changes in the concentration of the trivalent chromium in the leachate in the early stage of leaching. In the sequential leaching process, some secondary phases that were difficult to dissolve might be generated in the EAFS, and the chromium-bearing primary minerals could be subsequently sequestered. The chromium concentration in the leachates was dependent on the diffusion rate of chromium passing through the secondary phase layer rather than the dissolution of chromium-bearing primary minerals.

Consequently, steady chromium concentrations were achieved under different $L / S$ ratios during the latter leaching period. After a 15-day leaching period, the chromium concentrations stabilized at $5.2 \times 10^{-2}$, $3.8 \times 10^{-2}$, and $2.4 \times 10^{-2} \mathrm{mg} / \mathrm{L}$ when the $\mathrm{L} / \mathrm{S}$ ratios were $(10,20$, and 100$) \mathrm{g} / \mathrm{mL}$, respectively. This indicated that the concentration of chromium in the leachates would not decrease proportionally with the increase of $L / S$ ratio, which suggested that the chromium leaching from EAFS could be controlled conjunctively by the dissolution of primary phases and the precipitation of secondary phases.

\subsection{Geochemical model of chromium leaching}

Based on the dissolution/precipitation, thermodynamic, and kinetic control of the primary and secondary phases, a geochemical model of the leaching concentration of chromium from EAFS was established using the PHREEQC software. The PHREEQC speciation-solubil- 
ity module was used to estimate the chromium species and the solubility of the mineral phases in the leachates.

Firstly, the equilibrium concentrations of chromium under various $L / S$ ratios were simulated by PHREEQC. For comparison, the experimental data were obtained by averaging the chromium concentrations after stabilization for each of the $L / S$ ratios. Figure 6 shows the simulated and the experimental chromium concentrations as a function of the $L / S$ ratio. The simulated chromium equilibrium concentration values in the leachates were consistent with the results of the leaching test. This result suggested that the geochemical model established by PHREEQC could function as a potential method to assess the toxicity of the heavy metals released from solid wastes. The small deviation between the simulated and the measured values could be explained for two main reasons. First, chromium existed as separated and dissolved $\mathrm{Cr}_{2} \mathrm{O}_{3}$ in the EAFS, while the real compounds were taken into account when the geochemical model was established. Second, the solubility constants of the amorphous phases present in the EAFS were difficult to determine. Therefore, only the crystal phases and their solubility constants could be determined and used in the geochemical model. To improve the geochemical model, the solubility constants of amorphous and crystal phases in the EAFS should be determined.

To explore the mineral phases controlling the chromium concentration in the leachates, the major chromium-bearing original and secondary minerals were selected. Next, the saturation index (SI) of these minerals, which could be used to indicate the minerals' dissolution or precipitation in leachates, was calculated using the PHREEQC software (Figure 7). Spinel phases in the EAFS, such as $\mathrm{Mg}-\mathrm{Cr}$ spinel $\left(\mathrm{MgCr}_{2} \mathrm{O}_{4}\right), \mathrm{Fe}-\mathrm{Cr}$ spinel $\left(\mathrm{FeCr}_{2} \mathrm{O}_{4}\right)$, are original chromium-bearing minerals in the EAFS and insoluble during leaching under normal conditions. Therefore, the SI values of the $\mathrm{MgCr}_{2} \mathrm{O}_{4}$ and $\mathrm{FeCr}_{2} \mathrm{O}_{4}$ were negative and far below -1.5 . The SI of

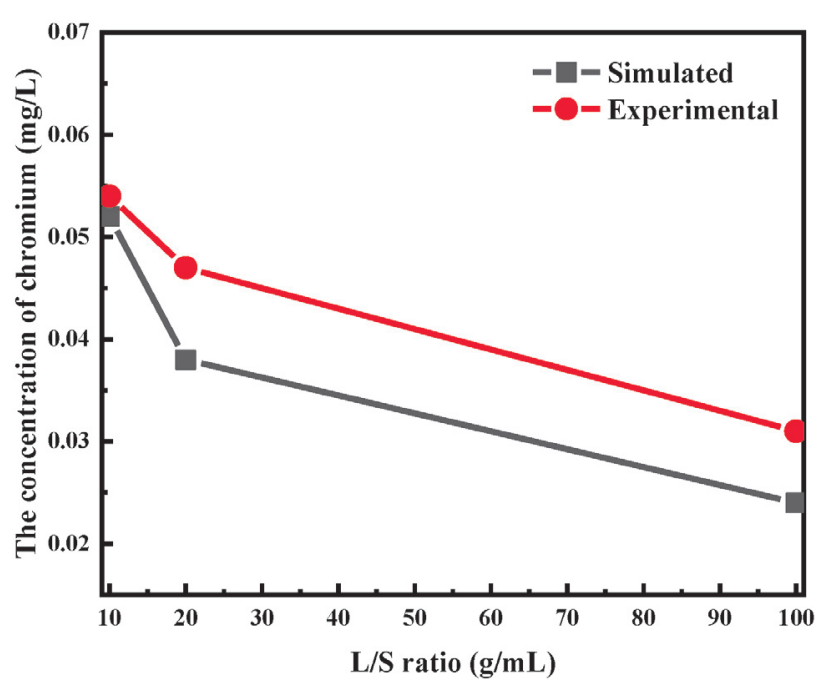

Figure 6: Simulated and experimental chromium concentration under different $L / S$ ratio

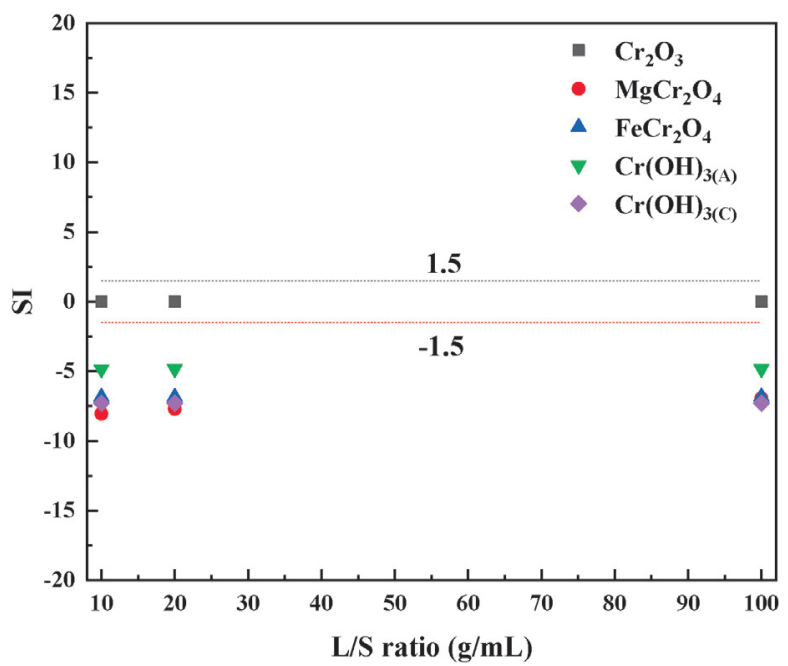

Figure 7: The saturation indices of Cr-bearing phases in the leachate

$\mathrm{Cr}_{2} \mathrm{O}_{3}$ was 0 under the $L / S$ ratios of $(10,20$, and 100) $\mathrm{g} / \mathrm{mL}$, and the $\mathrm{Cr}_{2} \mathrm{O}_{3}$ that was separated or dissolved in the pseudo-binary phases could release $\mathrm{Cr}^{3+}$ into the leachate and control the chromium concentration at various $L / S$ ratios. After extracting into the leachates, chromium would exist in the chromium-bearing secondary phases, mainly as $\mathrm{Cr}$ (III)-hydroxides, such as amorphous $\mathrm{Cr}(\mathrm{OH})_{3(\mathrm{~A})}$ and crystalline $\mathrm{Cr}(\mathrm{OH})_{3(\mathrm{C})}$. The SI of $\mathrm{Cr}(\mathrm{OH})_{3(\mathrm{~A})}$ and $\mathrm{Cr}(\mathrm{OH})_{3(\mathrm{C})}$ were -4.83 and -7.28 , respectively. This indicated that these phases were unstable in the leachate and could be converted into $\mathrm{Cr}(\mathrm{OH})_{4}{ }^{-}{ }^{28}$ According to the solubility model of chromium established by R. Baciocchi et al., ${ }^{21}$ chromium release could be controlled by either the chromium oxide or hydroxide phases. The dynamic leaching mechanism of chromium in EAFS slag can be expressed by Equations (2-4):

$$
\begin{aligned}
\mathrm{Cr}_{2} \mathrm{O}_{3(\mathrm{~s})}+\mathrm{H}_{2} \mathrm{O}_{(\mathrm{l})} & =2 \mathrm{CrO}_{2}^{-}+2 \mathrm{H}^{+} \\
\mathrm{CrO}_{2}^{-}+\mathrm{H}_{2} \mathrm{O}_{(\mathrm{l})} & =\mathrm{Cr}(\mathrm{OH})_{3(\mathrm{~s})} \\
\mathrm{Cr}(\mathrm{OH})_{3(\mathrm{~s})}+\mathrm{H}_{2} \mathrm{O}_{(\mathrm{l})} & =\mathrm{Cr}(\mathrm{OH})^{-}+4 \mathrm{H}^{+}
\end{aligned}
$$

\section{CONCLUSIONS}

EAFS was found to contain mostly merwinite, magnetite, larnite, gehlenite, eskolaite, spinel, and perovskite. Chromium was mainly dispersed in the magnesia-chromium spinel and the $\mathrm{Fe}-\mathrm{Cr}$ alloy, while a small amount was dispersed in the merwinite matrix.

During the sequential leaching process, the leachate was present as an alkaline and reductive solution. As the $L / S$ ratio increased, the $\mathrm{pH}$ decreased, while the Eh increased. Trivalent chromium was the predominant species in the leachates.

After 15 consecutive days of growth, the chromium concentration in the leachate stabilized. The dissolution of primary phases and the precipitation of secondary phases conjunctively controlled the concentration of the chromium in the leachate. 
The geochemical model of chromium leaching developed using the PHREEQC software was found to be a reliable method for assessing the toxicity of heavy metals released from solid wastes. Lastly, the dissolution of the primary phase- $\mathrm{Cr}_{2} \mathrm{O}_{3}$ in the EAFS controlled the dissolution of chromium.

\section{Acknowledgments}

The authors gratefully acknowledge support from the National Natural Science Foundation of China (No. 51704119, 51574108) and the Key Research and Development Project of Tangshan (No. 19140205F).

\section{REFERENCES}

${ }^{1}$ H. Shen, E. Forssberg, U. Nordström, Physicochemical and mineralogical properties of stainless steel slags oriented to metal recovery. Resources, Conservation and Recycling, 40 (2004) 3, 245-271, doi:10.1016/s0921-3449(03)00072-7

${ }^{2}$ B. Liu, J. Li, Y. Zeng, Z. Wang, Toxicity assessment and geochemical model of chromium leaching from AOD slag, Chemosphere, 144 (2016) 2052-2057, doi:10.1016/j.chemosphere.2015.10.103

${ }^{3}$ J. Zheng, M. Shi, J. Li, C. Guo, L. Zhang, Reductive immobilization of hexavalent chromium in contaminated soil and ground water system, Chinese Journal of Environmental Engineering, 9 (2015) 7 3077-3085, (In Chinese with English abstract)

${ }^{4}$ P. Chaurand, J. Rose, J. Domas, J. Bottero, Speciation of Cr and V within BOF steel slag reused in road constructions, Journal of Geochemical Exploration, 88 (2006) 1-3, 10-14, doi:10.1016/j.gexplo. 2005.08.006

${ }^{5}$ G. Lee, J. G. Hering, Oxidative Dissolution of Chromium(III) Hy-

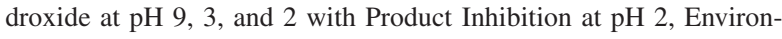
mental Science \& Technology, 39 (2005) 13, 4921-4928, doi:10.1021/es048073w

${ }^{6}$ G. B. Douglas, L. A. Wendling, S. Coleman, Productive use of steelmaking by-product in environmental applications (I): Mineralogy and major and trace element geochemistry, Minerals Engineering, 35 (2012), 49-56, doi:10.1016/j.mineng.2012.04.013

${ }^{7}$ C. Jing, S. Liu, G. P. Korfiatis, X. Meng, Leaching behavior of $\mathrm{Cr}(\mathrm{III})$ in stabilized/solidified soil, Chemosphere, 64 (2006) 3, 379-385, doi:10.1016/j.chemosphere.2005.12.039

${ }^{8}$ A. Facchinelli, E. Sacchi, M. Tararbra, D. A. De Luca, Assessment of chromium release from steel manufacturing waste, Environmental Geochemistry and Health, 23 (2001) 3, 235-240, doi:10.1023/ a:1012217908019

${ }^{9}$ J. F. P. Gomes, C. G. Pinto, Leaching of heavy metals from steelmaking slags, Revista De Metalurgia, 42 (2006) 6, 409-416, doi:10.3989/revmetalm.2006.v42.16.39

${ }^{10}$ K. B. Lateef, A. R. Sheikh, M. S. Nurulakmal, N. Baharun, Evaluation of the Leaching Behavior of Hexavalent Chromium from Malaysian Electric Arc Furnace Steel Slag, Advanced Materials Research, 652-654 (2013), 1628-1632, doi:10.4028/www.scientific.net/amr. 652-654.1628

${ }^{11}$ R. Wang, R. Chen, L. Shi, Beneficial use of stainless steel EAFS as composite cement admixture and its heavy metals leaching risk analysis, Baosteel Technical Research, 3 (2009), 14-18, (In Chinese with English abstract)

${ }^{12}$ C. Liu, R. P. Côté, Controlling chromium slag pollution utilising scavengers: A case of Shandong Province, China, Waste Manage- ment \& Research, 33 (2015) 4, 363-369, doi:10.1177/ $0734242 \times 15574562$

${ }^{13}$ E. Belhadj, C. Diliberto, A. Lecomte, Characterization and activation of Basic Oxygen Furnace slag, Cement and Concrete Composites, 34 (2012) 1, 34-40, doi:10.1016/j.cemconcomp.2011.08.012

${ }^{14}$ M. Kuhn, D. Mudersbach, Treatment of liquid EAF-slag from stainless steelmaking to produce environment friendly construction materials, SCANMET II-2nd International Conference on Process Development in Iron and Steelmaking, Lulea, 2004, pp. 369

${ }^{15}$ W. J. Deutsch, R. Siegel, Groundwater geochemistry: fundamentals and applications to contamination, Lewis Publishers, New York, 1997

${ }^{16}$ V. Ettler, O. Sebek, T. Grygar, M. Klementová, P. Bezdic?ka, H. Slavíková, Controls on Metal Leaching from Secondary Pb Smelter Air-Pollution-Control Residues, Environmental ence \& Technology, 42 (2008) 21, 7878-7884, doi:10.1021/es801246c

${ }^{17}$ A. M. Fällman, Leaching of chromium and barium from steel slag in laboratory and field tests - a solubility controlled process?, Waste Management, 20 (2000) 2-3, 149-154, doi:10.1016/s0956-053x(99) 00313-X

${ }^{18}$ Y. W. Chen, S. Tian, Improvement of determing total chrome with spectrophotometric method, Heilongjiang Environmental Journal, 32 (2008), 61-66, (In Chinese with English abstract)

${ }^{19}$ J. W. Ball, D. K. Nordstrom, Critical Evaluation and Selection of Standard State Thermodynamic Properties for Chromium Metal and Its Aqueous Ions, Hydrolysis Species, Oxides, and Hydroxides, Journal of Chemical \& Engineering Data, 43 (1998) 6, 895-918, doi:10.1021/je980080a

${ }^{20}$ V. Ettler, P. Piantone, J. C. Touray, Mineralogical control on inorganic contaminant mobility in leachate from lead-zinc metallurgical slag: experimental approach and long-term assessment, Mineralogical Magazine, 67 (2003) 06, 1269-1283, doi:10.1180/ 0026461036760164

${ }^{21}$ R. Baciocchi, G. Costa, A. Polettini, R. Pomi, Effects of thin-film accelerated carbonation on steel slag leaching, Journal of Hazardous Materials, 286 (2015), 369-378, doi:10.1016/j.jhazmat.2014.12.059

${ }^{22}$ C. E. Halim, S. A. Short, J. A. Scott, R. Amal, G. Low, Modelling the leaching of $\mathrm{Pb}, \mathrm{Cd}, \mathrm{As}$, and $\mathrm{Cr}$ from cementitious waste using PHREEQC, Journal of Hazardous Materials, 125 (2005) 1-3, 45-61, doi:10.1016/j.jhazmat.2005.05.046

${ }^{23}$ G. Adegoloye, A. L. Beaucour, S. Ortola, A. Noumowe, Mineralogical composition of EAF slag and stabilised AOD slag aggregates and dimensional stability of slag aggregate concretes, Construction and Building Materials, 115 (2016), 171-178, doi:10.1016/j.conbuildmat. 2016.04.036

${ }^{24}$ F. Engström, M. L. Larsson, C. Samuelsson, ̊. Sandström, R. Robinson, B. Björkman, Leaching Behavior of Aged Steel Slags, Steel Research International, 85 (2013) 4, 607-615, doi:10.1002/srin. 201300119

${ }^{25}$ L. De Windt, P. Chaurand, J. Rose, Kinetics of steel slag leaching: Batch tests and modeling, Waste Management, 31 (2011) 2, 225-235, doi:10.1016/j.wasman.2010.05.018

${ }^{26}$ P. Chaurand, J. Rose, V. Briois, L. Olivi, J. L. Hazemann, O. Proux, J. Y. Bottero, Environmental impacts of steel slag reused in road construction: A crystallographic and molecular (XANES) approach, Journal of Hazardous Materials, 139 (2007) 3, 537-542, doi:10.1016/j.jhazmat.2006.02.060

${ }^{27}$ Y. Samada, T. Miki, M. Hino, Prevention of Chromium Elution from Stainless Steel Slag into Seawater, ISIJ International, 51 (2011) 5 , 728-732, doi:10.2355/isijinternational.51.728

${ }^{28}$ B. Beverskog, I. Puigdomenech, Revised pourbaix diagrams for chromium at $25-300{ }^{\circ} \mathrm{C}$, Corrosion Science, 39 (1997) 1, 43-57, doi:10.1016/s0010-938x(97)89244-x 